\title{
On the language features of English contract translation
}

\author{
Yan Chen, Dai Yun \\ School of Foreign Languages, China University of Political Science and Law, Beijing, China \\ Email address: \\ susan_banban_923@hotmail.com (Yan Chen), hubeiiloveyou2008@163.com (Dai Yun)
}

\section{To cite this article:}

Yan Chen, Dai Yun. On the Language Features of English Contract Translation. International Journal of Language and Linguistics. Special Issue: The Sociolinguistics of a Changing World. Vol. 2, No. 6-2, 2014, pp. 1-5. doi: 10.11648/j.ij1l.s.2014020602.11

\begin{abstract}
Legal English emphasizes precise wording, fluent writing and abundant information. Its expression is obscure and the structure is complicated. The features of English law are widely criticized and also cause tremendous difficulties for understanding and application. English contract, a legal document which has instant effectiveness, clearly defines the responsibilities, rights and benefits of the parties, so its language is considerably different from general language. This paper seeks to analyze the lexical and syntactic features of English contract so as to better assist legal translation.
\end{abstract}

Keywords: English Contract, Lexical and Syntactic Features, Translation

\section{Introduction}

The increasing exchanges among different language areas in trade have greatly enhanced the role of translation in communication, and professional translators began to work for the massive needs (Yan Chen \& Huang Jingjing, 2014). With further development of the reform and opening up policy and the formation of international economic integration, foreign contracts and legal instruments become increasingly important owing to the fact that appropriate contract is indispensable in nearly all international activities in trade, finance and investment. The popularity of English contract gives rise to the unique stylistic features of English contract and also poses a challenge to the quality of translation. This paper first clarifies the lexical features including cases where the initial letter should be capitalized, the use of formal words, technical terms, archaic words, borrowed words and modal verbs, and further analyses the syntactic features and exemplifies why long sentences, declarative sentences and the usage of putting negative words ahead are common in English contracts.

\section{Lexical Features}

Contract, as a special kind of legal text, has its own language features which are remarkably reflected in vocabulary from the angle of linguistics. The use of vocabulary in contract indicates that contract is binding upon conclusion, and the contract terms are precise and accurate. The differences in lexical features between contract and other legal texts lie in the following six aspects: first letter to be capitalized; formal words; technical terms; archaic words; borrowed words; modal verbs.

\subsection{First Letter to be Capitalized}

Initials of words, like parties to the contract, organizations involved, international conventions, laws and regulations, documents and monetary names in a contract are often capitalized in order to draw attention and decrease the possibilities of disputes. For example, Parties to the contract: This contract is made by and between the Buyers and the Sellers, whereby the Buyers agree to buy the under-mentioned goods subject to the terms and conditions as stipulated hereinafter:

The organization involved: In case no settlement can be reached, the case at issue shall then be submitted for arbitration to the China International Economic and Trade Arbitration Commission in accordance with the provisions of the said Commission.

Relevant regulations and documents: The patent described in Article 2 is not issued within 30 days from signing this Contract.

Monetary name: The Joint Venture Company shall open foreign exchange accounts and RMB accounts with the Bank of China, Beijing Branch or other banks designated by the said bank.

In practice, there is another case where the initial of a word should be capitalized. It often occurs when this word is 
defined. By capitalizing a word, a special meaning is formulated. Here are two sample clauses:

Wherever used in this contract, the word "Goods" shall mean the goods that Buyer has agreed to purchase from Seller under this contract.

Buyer hereby agrees to purchase from Seller ten frying pans, hereinafter called the "Goods".

In the two examples above, when the word "goods" are capitalized, it indicates a particular meaning in certain context. As a result, it is possible that the meaning of the same capitalized word varies according to different cases.

\subsection{Formal Words}

The contract, formulated by the parties to the transaction, clearly and directly regulates the meaning and scope of rights, obligations, and codes of the conduct (Wei Hua, 2007). In order to demonstrate its authority, its language should be formal, precise, accurate and free from colloquial words or expressions, personal feelings and biased opinions. For example, "at the close of the fiscal year" is frequently used instead of "in the end of the fiscal year"; "prior to" rather than "before" is applied, "in effect" is used to replace "in fact".

Example 1: When it comes to translating Article 57 of Contract Law of People's Republic of China, the following is a more popular sample, frequently invoked and recommended by the authorities.

If a contract becomes invalid, or is rescinded or terminated, the validity of its independently existing clauses pertaining to the settlement of disputes shall not be affected.

The phrase "you guan" has several translations in English, for example, "relevant to", "connected with" etc. While rendering the above Article into English, the translator has to take formality of the legal text into consideration. Although "connected with" and "relevant to" share the same meaning with "pertaining to", the latter is more formal and so it prevails.

Example 2:

Due to Force Majeure, the Sellers shall not be held responsible for the delay in shipment of the goods.

In English contract, "due to" or "by virtue of" is often used for explanation. The phrase "because of" is relatively informal and rarely seen in legal text.

\subsection{Technical Terms}

Technical terms, owing to their unambiguous, accurate description of the trading process, contribute to the formality of the legal text. Technical terms of legal English mainly fall into two categories. One is the specialized vocabulary employed only in legal English, for example, carrier (an individual or organization that contracts to transport passengers or goods for a fee, often seen and used in the context of Maritime time), equity (the system of law or body of principles originating in the English Court of Chancery and superseding the common and statute law, frequently appears in the context of common law legal system), etc. (Bryan A. Garner, 2009). The second category includes common words with special meaning in the legal sense, such as:

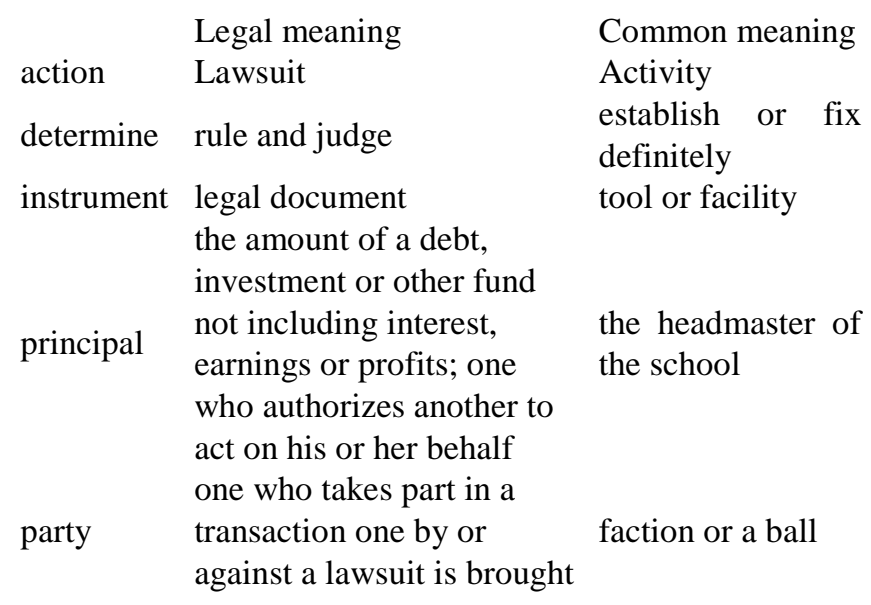

Example 1:

If the client fails to pay remuneration or the prices for material, the contractor has the right of lien on the work results, unless the parties stipulate otherwise.

"Lien" means "right to keep somebody's property until a debt owed in connection with it (for repair, transport, etc) is paid" (Oxford Advanced Learner's English-Chinese Dictionary, Fourth edition, p.857). This word only appears in a legal text.

Example 2:

(1) A contract that is entered into by an actor without the right of agency, in excess of the right of agency or beyond the expiration of the right of agency, in the name of a principal and without ratification by the principal, shall have no binding force on the principal, and the actor shall bear the responsibility therefore; (2) The interest on a loan may not be deduced from the principal in advance. If the interest is deduced from the principal in advance, the loan shall be repaid and the interest shall be calculated according to the actual amount of the loan provided (The English Version of Contract Law of People's Republic of China, p.1170).

The noun "principal" contains several meanings, namely "the headmaster", "the main actor", "the major party or the most important person", etc. The word means "dai li ren" in example (1), that is "a person from whom another one acts as his agent in business or law". Whereas in example (2), the "principal" refers to "the amount of a debt, investment or other fund except interest, earnings or profits", which means "ben jin". Therefore, it is likely to cause confusion if the specific meaning of the technical terms are unknown.

Example 3:

The trademark office shall make a determination about the relevant materials of a case, inform the administrative department of the province (autonomous region, municipality directly under the Central Government) where this case occurred of the decision, and send a copy of the decision to the administrative department of the province (autonomous region, municipality directly under the Central Government) where the involved parties are located (Article 8 of Regulation of the Recognition and Protection of Well-known Trademark). 
According to the context, the term "ren ding" is a decision made after analysis of the relevant materials, not the materials themselves. Consequently, "make a determination" is more appropriate than the use of "make a decision".

\subsection{Archaic Words}

The old style of English words, like hereof, hereby, thereafter and whereby, are very formal and solemn expressions. In modern English and even in written English, they are not commonly used, but enjoy very high frequency in English contracts (Chen Bangguo, 2009). The contract is effective as of the date when signed by the parties concerned, so the language of the contract should reflect this feature. Extensive use of archaic words not only render contracts highly formal and dignified, but condense the contractual language so that contracts are endowed with a strong formality and shielded from language repetition and ambiguity.

Most of archaic words are compound adverbs, adding one or several prepositions to adverbs, e.g. "after, at, by, from, in, of, to, under, upon" to "here, there, where" (Fu Weiliang, 2002). For example, herewith, herein, hereinafter, hereunder, therein, thereinafter, thereto, whereas, whereof, whereby and wherein, etc. Such compounds scatter everywhere in the English version of Contract Law of People's Republic of China.

Article 11: "Written form" as used herein means any form which renders the information contained in a contract capable of being reproduced in tangible form such as a written agreement, a letter, or electronic text (including telegram, telex, facsimile, electronic date interchange and e-mail);

Article 32: If the parties enter into a contract in the form of a contract instrument, the contract is executed at the time when both parties put their signature or affix their seals thereto (The English Version of Contract Law of People's Republic of China, p.1256).

In the above two Articles, "herein" refers to "in this document", and "thereto" means "to it". Both of the words are exclusively used in the legal text.

\subsection{Borrowed Words}

Loanwords are words adopted by the speakers of one language from a different language (the source language). A loanword can also be called a borrowing. The abstract noun borrowing refers to the process of speakers adopting words from a source language into their native language. "Loan" and "borrowing" are of course metaphors, because there is no literal lending process. There is no transfer from one language to another, and no "returning" words to the source language. The words simply come to be used by a speech community that speaks a different language from the one these words originated in.

As globalization is becoming overwhelming, many borrowed words are used in English contract. Many borrowed words are derived from Latin or French for their meaning is relatively stable and conducive to precisely embody the concept. Despite the call of replacement of Latin terms by modern words, lawyers, especially those from English speaking countries still have a great preference to them. Some phrases which are commonly seen and used in legal documents are listed as below. De facto (in point of fact), De Jure (as a matter of law), ad valorem duty (duty levied based on price), bona fide holder (a Latin which means a holder in good faith), pro rata tax rate (a Latin which is equal to proportional tax rate), Inter alia (especially), Force Majeure (a French indicating act of God, that is, something happens beyond human control and expectation).

\subsection{Modal Verbs}

The main content of English contract is to stipulate rights and obligations of the relevant parties. Klaudia Gibová (2011) found in his study that Modal verbs emerge as a prime component in the EU institutional-legal language disclosing a semantic flexibility to fulfil various communicative tasks in the interaction between the EU institutions and their addressees. Modal verbs like "shall" and "may" are frequently used. Among all modal verbs, the usage of the modal auxiliary "shall" is most extraordinary. The major function of this modal auxiliary is not to express futurity as in the common speech of English but to impose an obligation. "Shall" is mainly adopted to express a mandatory mood. The words "shall" and "shall not" normally indicate that someone must act or refrain from acting in order to accomplish the purpose of the provision (Chen Zhongchen, 1992); consequently, "shall" is very often translated into "ying gai", "ying”, "bi xu”. For example,

The parties shall observe the principle of good faith in exercising their rights and fulfilling their obligations.

\subsection{Syntactic Features}

English contract uses a special kind of legal English. Its instant effectiveness makes parties involved deliberate and meticulous in concluding and executing a contract. It is rigid and formal. These characteristics of the contract can also find manifestation in syntax: long sentences and declarative sentence.

\subsection{Long Sentences}

One striking syntactic features of English contract is the tendency to use long sentences to express complex ideas with accuracy and precision (Liu Qian, 2011). English contract is rigid and logical, and the use of long sentences could help accurately define rights and obligations of the relevant parties and leave no space for ambiguity and misunderstanding, which, as a result, may cause disputes and even heavy economic losses (Zhang Ligui, 2007). In order to convey all the compulsory sense and information at a particular point, it is necessary to cover all conceivable situations, conditions or requirements. Here are some examples.

(1) Within 30 days after the signing and coming into effect of this contract, the Buyer shall proceed to pay the price for the goods to the Seller by opening an irrevocable $\mathrm{L} / \mathrm{C}$ for the full amount of USD 30,000 in favor of the 
Seller through a bank at export port.

In this Article, there are two adverbial clauses. "Within 30 days after the signing and coming into effect of this contract..." is an adverbial clause of time; “...by opening an irrevocable L/C for the full amount of USD 30,000 in favor of the Seller through a bank at export port" is an adverbial clause of manner. They respectively prescribe the deadline and the way paying the price, so as to avoid disputes in practice.

(2) Where servants, agents or subcontractors of the Company carry out work under the direction of the Client, the Client shall be fully responsible for, and indemnify and hold harmless the Company against any claim, loss or damage of any kind, whether arising in contract in negligence, in equity or by statute or under any law connected in any way with the Services, Project or relationship established by this Agreement.

This is a complex sentence with 69 words, with the adverbial clause "servants, agents or subcontractors of the Company carry out work under the direction of the Client" introduced by "where" as a condition and the difficulty in understanding lies in the main clause where there is another shortened adverbial clause "whether arising in contract, in negligence, in equity or by statute or under any law connected in any way with the Services, Project or relationship established by this Agreement" introduced by "whether".

(3) This agreement is made and entered into by and between ABC Co. and DEF Co.

In fact, "by" and "between" share the same meaning, by intentionally being paralleled they play the function of emphasis, so does the term "made and entered into".

Some researches show the positive correlation between the extent of readability and the number of words in a sentence. Flesch (1962) has further made a quantitative research, showing the positive correlation between the extent of readability and the number of words.

Readability and Sentence Length

$\begin{array}{ll}\text { Extent of readability } & \text { Number of words } \\ \text { Very easy } & 8 \text { or less } \\ \text { Easy } & 11 \\ \text { Fairly easy } & 14 \\ \text { Standard } & 17 \\ \text { Fairly difficult } & 21 \\ \text { Difficult } & 25 \\ \text { Very difficult } & 29 \text { or more }\end{array}$

According to statistics drawn by Xu Ying (2003), the average sentence length of an English contract is 36.4, which is much greater than 29 , so it is unavoidable and natural that an English contract is long and somewhat painstaking to read English contracts.

\subsection{Declarative Sentence}

The Contract is a legal document agreed after several rounds of negotiations. It clearly lists the rights and obligations of the parties rather than posing questions or discussing issues, hence the basic sentence structure is constructed by declarative statements, and questions and interjectional expressions are sparse in English contract. Since the contract is a legally binding instrument, the rights and obligations of the parties under the terms are general to some degree; gradually most terms become international customs especially in business trade and investment (Chen Bangguo, 2009). Therefore, present tense is pervasive in an English contract. For example,

Before completion of the project, Party A may at any time increase or decrease the amount of work of the project.

This Article is to provide something after signing the contract, but present tense rather than future tense is adopted.

\section{Conclusion}

English contract as a legal instrument is well organized and neatly structured. Unlike other varieties of English, it presents some striking and unique features in lexis and syntax. Cases where the first letter needs to be capitalized, the use of formal words, frequent use of technical terms, and the use of archaic words, borrowed words and modal verbs, all are conspicuous features in English contract. In syntax, there are numerous long sentences and declarative sentences. The analysis of lexical and syntactic features of English contract will assist legal translation. In translation, besides proficient language expertise and abundant knowledge of economy and trade, a deep understanding of language features of English contract is also indispensable, owing to the accuracy and rigor of legal text. Profound study of language features of English contract is contributive to its translation and language communication in the long run.

\section{References}

[1] Bryan A. Garner. (2009). Black's Law Dictionary. United states of America: LawProse Inc.

[2] Chen Bangguo. (2009). A Discussion on the Language Features of Contract English. Journal of Wuha Institute of Shipbuilding Technology, 8, 22-26.

[3] Chen Zhongchen. (1992). Fa Chuang Yi Hua. International Translation Co., Ltd of China.

[4] Flesch Rudolf Franz. (1962). How to be brief: An index to simple writing. New York Harper \& Row.

[5] Fu Weiliang. (2002). Writing abstract of English Contract. Beijing: The Commercial Press International Co., Ltd.

[6] Gibová, K. (2011) "On Modality in EU Institutional-Legal Texts“" In English Matters II, edited by Alena Kačmárová, Prešov: Prešovská univerzita, pp. 6-12.

[7] Liu Qian. (2011). On the Strinking Stylistic Features of Contract English. 2011 Internation Conference on Computer and Network Engineerig (ICCNE 2011), V2-240.

[8] Oxford Advanced Learner's English-Chinese Dictionary, Fourth edition. 
[9] Regulation of the Recognition and Protection of Well-known Trademark. Retrieved December 20, 2012. From http: // www.ccpit-patent.com.cn/ references

Provisions_on_Recognition_ Protection _Well-known _ Trademarks.htm.

[10] The English Version of Contract Law of People's Republic of China. Retrieved December 20, 2012. From http://www.doc88.com/p-210659066797.html.

[11] Wei Hua. (2007). An Analysis on The Language Characteristics and Translation of English Contract. Technology Wedth in Gansu, 6.
[12] Xu ying. (2003). An Analysis of the Function of Contracts: Complex Expressions in English Contracts. Retrieved November $\quad 10, \quad 2012 . \quad$ From http://www.doc88.com/p-741873331442.html.

[13] Yan, C. and Huang J. J. (2014). The Culture Turn in Translation Studies. Open Journal of Modern Linguistics, 4, 487-494. http://dx.doi.org/10.4236/ojml.2014.44041.

[14] Zhang Ligui. (2007). Features and Translation of Foreign Contract English. Weekly magazine of Examination, 3, 24-27. 